\title{
Did Diversification Impact Economic Growth in Nigeria in the Last 20 Years of Democratic Government (1999-2019)? A Vector Error Correction Model
}

\author{
Temitope Abraham Ajayi \\ Department of Economics, Strathclyde Business School, University of Strathclyde. \\ Glasgow, United Kingdom
}

\begin{abstract}
Diversification of the Nigerian economy from oil-based to other non-oil sectors has become a recurrent economic solution to the growing challenges associated with the Nigerian economy. For the past 20 years of uninterrupted democratic government in Nigeria, the successive federal governments have focused on the development of the agricultural sector as a credible option for diversification, partly for the past positive roles of the agricultural sector in the Nigerian economy before the discovery of oil. Using the multivariate vector autoregressive (VAR) model on the data obtained from 1999 to 2019, this study applied the vector error correction (VEC) model to determine the impacts of diversification of the Nigerian economy on economic growth, focusing on the manufacturing and the agricultural sectors. To determine the underlying impact of the democratic experience in Nigeria with diversification, we utilised the political rights of the population as a proxy variable. The empirical results showed that there exists cointegration among the variables used to represent the manufacturing and the agricultural sectors, political rights, and per capita gross domestic product (GDP) growth rate within the Nigerian economy. The manufacturing sector has a positive impact on the growth of the Nigerian economy; however, the agricultural sector and the political rights of the Nigerian people have adverse effects on the real GDP growth rate, in the short run. The Granger Causality tests found no evidence of causality among the variables. This study concludes that the diversification policy of the Nigerian government should be multifaceted and that the political rights of the population are essential for the realisation of the diversification goal.

Keywords: Diversification, Nigeria, GDP, Cointegration.
\end{abstract}

DOI: $10.7176 / \mathrm{JESD} / 11-22-02$

Publication date: November $30^{\text {th }} 2020$

\section{Introduction}

The Nigerian economy is dominated by the oil sector, to a considerable extent. This sector has continued to play pivotal roles throughout the chequered history of Nigeria, since its discovery in 1956. Substantial evidence from the literature shows the potential exposure of oil-producing economies to various shocks caused by the instabilities in oil pricing and other exogenous factors. Budgetary allocation and fiscal planning of the Nigerian economy depend on the flow of oil rents to the government income, which has adverse economic effects (Sachs and Warners, 1999; Sevil, 2017; Collier and Hoeffler, 2005; Mehlum et al., 2014). There is considerable debate in the economic literature concerning the impacts of oil rents; however, evidence suggests that its impacts on Nigeria are not entirely adverse.

From a political perspective, Nigeria was governed by both the military and the democratic government, although the military governed the larger part of the Nigerian history. In the last two decades, Nigeria has transformed into a democratic government. Since 1999, the main issue was the diversification of the Nigerian economy from a mono-economy. The change to democratic government resulted from the assumption that the military government lacked the required economic plans to transform the Nigerian economy from an oil-based to a multi-sectoral economy. Further, the military government did nothing to prevent the rent-seeking behaviour and corruption that ensued from the flow of oil rents to the government income. The military government also abstained from any attempt to diversify the Nigerian economy so as not to tamper with the 'free money' which the crude oil provided.

The reliance on oil rents promoted corruption at a geometrical rate in Nigeria. It destroyed innovations and exposed the economy to various recessions, induced by the oil price instabilities. The cumulative effects of all the factors led to a weak and ageing infrastructure. Furthermore, oil rents led to a continued agitation for resource control by various groups, which bred ethnic militias for whom rent-seeking was the only opportunity to survive in the oil-producing states of Nigeria. In a report by the National Bureau of Statistics (2019) titled '2019 Poverty and Inequality in Nigeria', 40\% of the population in 2019, which was about 83 million people, lived in abject poverty. Although the Nigerian economy is officially the largest in Sub-Saharan Africa, evidence from the literature reveals that using the available metrics of development, Nigeria is far lower than South Africa and one of the worst performing countries among the oil-producing countries.

Given the above conditions, diversification emerged as one of the possible panaceas to resolve the 
challenges faced by the Nigerian economy. According to OECD/WTO (2019:142), 'Economic diversification can be defined as the shift towards a more varied structure of domestic production and trade to increase productivity, creating jobs and providing the base for sustained poverty-reducing growth'. Given the potentially favourable implications of diversification in an economy, the Nigerian government possibly agrees that it is the only credible option for economic growth. Several development plans have been proposed in the past decades. However, none were able to address the particular problem associated holistically with the Nigerian economy. Nearly all the growth plan failed during the implementation stage.

The main focus of all the democratic governments in Nigeria since 1999 was diversification of the economy. The agricultural sector used to be the mainstay of the Nigerian economy before the discovery of oil, contributing over 50\% to the aggregate GDP and export earnings (Odularu, 2010). Given the existence of large arable land for crop production and massive livestock like cattle, sheep, poultry products, and the like, the Nigerian economy had the capability to export a large amount of the agricultural produce in addition to feeding the population. However, the contribution of the agricultural sector to real GDP became insignificant since the discovery of oil. For instance, in the year 1981, the share of agriculture in the real GDP was $0.16 \%$; in 1991 it was $0.19 \%$, which rose to merely $0.25 \%$ in 2019 (Central Bank of Nigeria Statistical Bulletin, 2019).

The meagre contribution of the agricultural sector to the GDP initiated the rural to urban migration problems in Nigeria. It fuelled chronic shortage of food supply, complicated the existing urban unemployment, and contributed to the rising total unemployment. In 2013, the total unemployment rate was 3.703\%, which jumped to $8.531 \%$ in 2019. (World Bank Development Indicators, 2020). Due to the perennial fluctuations in the flow of oil rents to the income of the Nigerian government, efforts have been taken to revitalise the agricultural sector to achieve food sufficiency and increase its contribution to the aggregate GDP. Most of the agricultural practises in Nigeria follow the peasant agricultural mode of production that can barely meet the demands of a limited population and constitute an insignificant volume for exports. Moreover, agriculture constitutes the primary sector, and economic literature indicates that in the age of globalisation, its aggregate contributions are minimal which cannot form the basis of economic growth in many industrialised countries. Despite the above, evidence from the literature shows that the agricultural sector has continued to play significant roles in the economies of many developed and emerging countries such as Brazil and the Netherlands.

In order to maximise the gains from diversification, the multiplicity of approach is necessary. In the context of Nigeria, the combination of agriculture led diversification with manufacturing and service-based diversification is likely to be the best option for growth. The economic experience of the developed world indicates that a mixture of diversification options have varying results, but overall, the effect had been positive for economic growth. For instance, the U.S., the U.K., Saudi Arabia, and the UAE produce oil, but they have highly diversified economies with varying degrees of contributions from all their economic sub-sectors. The manufacturing sector's contribution to Nigeria's GDP has been marginal for decades. Expectations were that with the formation of the democratic government, improvements would follow. However, in 2019, the contribution of the manufacturing sector to the GDP was merely $0.09 \%$ (See Table 1 ).

One of the challenges confronting the development of the manufacturing sector in Nigeria is the high cost of production resulting from weak infrastructures, such as lack of electric supply, poor road networks, unfriendly operating environment, corruption, bureaucratic interferences, and substandard raw materials, to mention a few.

In an attempt to improve the manufacturing sector, the Nigerian government invested in infrastructural projects such as the construction and upgrading of the railway systems to link the states together and the liberalisation of the power sector to improve power supply. Although some of these policy initiatives have come with various shortcomings or policy conflicts. Substantial evidence in the economic literature shows that the development of the manufacturing sector is positively correlated with the economic growth of an economy. As a corollary to the above, the service sector and the sub-sectors constitute another vital area that the Nigerian government can pursue to achieve a multiplicity of approach in its diversification objectives. Although the contributions of the service industry to the GDP of Nigeria is relatively minimal, sectoral contributions of industries such as finance and insurance, transportation, human health, and education are critical to the growth of any economy. Therefore, it is empirically justifiable to determine the impacts of diversification on the growth of the Nigerian economy, especially within the last 20 years of uninterrupted democratic government.

There exists a large body of debates and empirical work on the relationship between diversification and economic growth in Nigeria. Many of these studies were conducted during the military regime (Olaleye et al., 2013; Godwin and Ubong, 2015; Esu and Udonwa, 2015; Ayodele et al., 2013). However, no study has focused entirely on the post-military era, studying the economic diversification in Nigeria, specifically from 1999 to 2019 , which represents the first 20 years of uninterrupted democratic government in the country. This study carves out a niche for itself in this regard. The rest of the study is organised into seven sections. Section 1.2 contains a summary of our contribution to the literature. Section 2 consists of the aims and objectives of the study. Section 3 provides the literature review. Section 4 enumerates the methodology used. Section 5 presents the Granger Causality tests. Section 6 analyses the impulse response function and variance decomposition function, and 
finally, Section 7 concludes.

\subsection{Originality and Contribution to the Literature}

Previous studies emphasised that justified diversification is crucial for economic growth, but the military government lacked the technical knowledge and the intent to diversify the Nigerian economy from a monoeconomy. This stimulated our interest and therefore, we conducted a study investigating the diversification effects on the growth level of the Nigerian economy within the first 20 years of a sustained democratic government in the country. This study represents the first attempt ever to carry out a research work studying the diversification impacts on Nigerian economic growth in the post-military period of 1999 to 2019.

\section{Aim and Objectives}

The broad aim of this empirical study was to investigate the relationship between diversification and the economic growth in Nigeria from 1999 to 2019. The specific objectives of this study were as follows:

[i] To examine the impacts of manufacturing-led diversification on the Nigerian economic growth.

[ii] To investigate the linkage between the diversification of the Nigerian economy via the agricultural sector and economic growth.

[iii] To determine the implications of the democratic effects, using the political rights of the population, on diversification and long-term economic growth of Nigeria.

[iv] To forecast the magnitude and pattern of variation in the manufacturing and agricultural sectors explained by the real GDP growth rate and vice versa.

\section{The Review of Related Literature}

The primary need to diversify the economic base of Nigeria arose due to the uncertainties in the future implications of its oil rents. Oil rents account for approximately $80 \%$ of the total government income in Nigeria, which is very substantial (CBN, 2010). However, attempts to diversify the Nigerian economy are prone to mutual suspicions by the government and the population. Onodugo et al. (2013) examined the impact of diversification on the Nigerian economy and found an insignificant impact of non-oil exports on the growth of the economy. Statistical evidence about the contribution of the non-oil sector to the Nigerian government's total revenue has not been robust for the past decades. For instance, non-oil sector accounted for an average of about $0.318 \%$ of the Nigerian government's total revenue from 1981 to 2019 (Central Bank of Nigeria Statistical Bulletin, 2019). Specifically, it rose from $0.35 \%$ in 1981 to merely $0.46 \%$ in 2019. Despite this weak outlook, successive governments had put in considerable efforts to diversify the Nigerian economy to achieve the macroeconomic objective of economic growth (Olaleye et al. .2013). Empirical evidence from Onayemi and Ishola (2009) indicated that with an increase in export promotion policy, especially in the non-oil commodities, per capita output would rise. To corroborate this linkage, Olayiwola and Okodua (2013), focused on export-led growth and contended that the development of the non-oil sectors in Nigeria might offer opportunities for an increase in export earnings and perhaps, economic growth. However, Nigeria's non-oil export contributions to the government revenue were minimal and insignificant for the growth of the economy. This potentially limited the efforts of the Nigerian government to fully embrace diversification.

Henry and Olabanji (2013) applied the Johansen cointegration approach to investigate the relationship between non-oil exports and economic growth in Nigeria. The study identified that diversification of the Nigerian economy to other non-oil sectors is essential and that the government must encourage the export of the non-oil commodities to promote economic growth. Substantial evidence from the literature demonstrates that some of the emerging economies, particularly in Asia, have been able to develop partly from diversification. Specifically, Young (1995) in his empirical work opined that increase in per capita income among the newly industrialised countries of East Asia was due to the economic diversification, which had positive effects on the labour force and technological know-how. Abogan et al. (2014), using the ordinary least squares method to examine the contributions of non-oil exports to the economic growth in Nigeria, showed that non-oil exports positively contributed to the economy's growth. In this study, we contradict the idea of positive contributions of the non-oil sectors on economic growth. Empirical literature demonstrates that agriculture belongs to the primary sector, and its practises followed in Nigeria, are still, in the traditional stage. Therefore, there exists a likelihood that the relationship between agricultural exports and economic growth rate of the country is insignificant and perhaps, negative. The volume of agricultural food exports is considerably low, and contrary to some assumptions in the literature, Nigeria still imports some food items that potentially make the net effect of agricultural food export negative. To buttress the concept above, Adesoji and Sotubo (2013) conducted an empirical work on the diversification of the Nigerian economy to other non-oil exports, with the agricultural sector and solid minerals as the focal points, using the cointegration approach. The study concluded that the contributions of the non-oil exports to the GDP are substantially weak and below an optimal standard, thereby incapable of stimulating economic growth. 
From the review of the related literature above, we deduced that the challenges to economic growth in Nigeria are two-fold. The first is the instabilities in oil pricing and its uncertain future, which has compelled Nigeria to seek an alternate panacea in the form of economic diversification. The second challenge is the overreliance of the Nigerian diversification policy on the agricultural sector, which is still underdeveloped. Previous literature on diversification and the Nigerian economy had focused more on the agricultural sector. The premises of those propositions were that the historical effects of agriculture on the Nigerian economic growth were optimistic before the 'oil years'. However, the world has moved away from pre-industrial years, when agriculture benefitted Nigeria substantially for economic growth. There is a need to extend the portfolios of economic diversification to other relevant sub-sectors, such as the manufacturing sector, as carried out in this study. We developed this study to address this research gap and observed the impacts of diversification, focusing on other economic sectors in addition to agriculture in Nigeria.

\subsection{Theoretical Perspective}

The theoretical perspective of this study drew support from three models explained below.

3.1.1 Hypothesis of Comparative Cost Advantage

David Ricardo (1817) a classical economist propounded the theory of comparative cost advantage. This theory is based on the hypothesis of trade specialisation. It demonstrates that a country should concentrate its productive capacities on those products or sectors which have the lowest opportunity costs. The Nigerian economy consists of three key sectors: agriculture, industry, and the service sectors, with each of them consisting of various subsectors, according to the Central Bank of Nigeria statistical bulletin (2019). Given the domination of the oil subsector under the Nigerian industry sector, various arguments have been advanced by the scholars regarding the development of the economy through other sub-sectors, mainly the agricultural food exports. The economic justification for such a proposition was based on the assumption that Nigeria has a comparative advantage in the production of agricultural food products.

3.1.2 Solow-Swan Neo-Classical Growth Model

The neo-classical growth model of Solow (1956) is based on the basic tenets that capital stock accumulation and technological progress are the primary drivers of economic growth. The model examined the changes in capital stock, total labour employment, and technology to actualise the objective of economic growth. It incorporated the effects of knowledge or human capital on the economy. Moreover, the Solow model contended that savings are a precondition for investment, and an increase in savings leads to a higher level of investment. Within the Nigerian economy, the Solow model underscored the need to augment the agricultural food exports-led diversification along with other alternatives, such as the service sub-sector, which might increase total labour employment and the level of savings. Evidence from the literature reveals that the meagre contribution of the non-oil sectors to the Nigerian economy could only be meaningful if some proportions of the non-oil income are saved or invested for infrastructural development in the economy (Soludo, 2007).

3.1.3 The Endogenous Growth Theory

The theoretical stand of the endogenous model is based on the assumptions of Romer (1990), Grossman and Helpman (1991a), and Agbion and Howitt (1992), which focused on technological change. The model expanded the idea of property rights, anti-trust, and competition. The free market mechanism potentially enhances an opportunity to open the economy for research and development (R\&D). The endogenous model dictated that the pursuit of economic diversification should probably not be put on the primary sector alone, as being advocated for, in most of the developing oil-producing economies in Sub-Saharan Africa and particularly, Nigeria. Evidence from the literature suggests that an investment in R\&D is capable of stimulating growth, as experienced in the economies of the developed states.

\section{Methodology of the Study}

This study applied the VAR model developed by Johansen (1990) and Johansen and Juselius (1992; 1994). This model permits each variable in the system to examine its effects on itself as well as on other variables without the imposition of the theoretical structure on the estimates. This attribute justified its usage in this study. Variance decomposition and impulse response functions enable the interpretation of a VAR model. Fundamentally speaking, this allows the identification of the relationships among all the variables used symmetrically since the structure allows each variable to construct a linear function of past lags of itself as well as the past lags of every other variable in the system of the equation model. The precondition tests for the application of a VAR model are the determination of the optimal lag structure, followed by the unit root test or the stationary test. By implication, the set of variables to be utilised must not be stationary at levels; however, their first difference must exhibit stationarity. Next, the Johansen cointegration tests were conducted to determine if the model equation has a long-run or a short-run relationship; in case of the former, the VEC model is applied and the VAR model, otherwise. Further, VAR estimate test along with impulse response function, variance decomposition tests, and Granger Causality test were conducted. In this study, we utilised the VEC 
model based on the output result of the Johansen cointegration test.

\subsection{The Specification of the Model}

In our attempt to determine the relationship between economic growth and diversification of the Nigerian economy into two vital non-oil sectors, namely the manufacturing and the agricultural sector during the first 20 years of democratic government in Nigeria, we utilised the VAR model to determine the causality and examine the effects of shocks via the impulse response function and the variance decomposition test. The primary aim of this study was to determine whether the Nigerian economic growth is cointegrated with the manufacturing sector (mas) and the agricultural sector (ags), along with the political rights (pol) of the citizenry. We sourced the data for manufacturing value-added as a percentage of GDP and per capita real GDP growth rate from the World Bank Development Indicators (2020), for the agricultural contributions as a percentage of GDP, from the Central Bank of Nigeria statistical bulletin (2020), and for the political rights metric data, from Quality of Governance

Institute, Groningen University. Functionally speaking, $Y_{t}=($ mas, $a g s$, pol $)$. Using a modified version of Johansen and Julius (1992) model, we expressed our VAR model as: $Y=$ $D_{0}+D_{1} X_{1}+D_{2} X_{2}+D_{2} X_{g} \ldots \ldots \ldots D_{k} X_{K} \ldots \ldots \ldots \ldots \ldots \ldots \ldots \ldots \ldots \ldots \ldots \ldots$

From equation (1), Y was our regressand or the dependent variable, $D_{0}$ implied the intercept, and $D_{1}, D_{2}, D_{3}$ lu $D_{k}$ were the coefficients of regression to be explained by, $X_{1}, X_{2}, X_{3}, \ldots \ldots X_{k}$ which were the regressors. Using the specific variables for this study, (1) was written as follows:

$\Delta g r o_{t}=D_{0}+D_{1} \operatorname{mas}_{\mathrm{t}}+D_{2} a g s_{t}+D_{3}$ pol $_{t}+\mu_{t} \ldots$

In the above equation, $\mathrm{t}=1,2, \ldots \ldots, \mathrm{n}$ and $g r o_{t}$ denotes the per capita real GDP growth rate, mas $_{t}$ is the manufacturing sector total value-added as a percentage of GDP, $a g s_{t}$ is the total agricultural sector contributions as a percentage of GDP, and pol $_{t}$ represents the political right of the population. It ranges from a lower bound of 1 to a higher bound of 7 . The stochastic disturbance is $\mu_{t}$. $D_{0}$ is the unknown intercept and $D_{1}, D_{2}$, and $D_{3}$ are the parameters to be determined. Following the work of Johansen and Juselius (1992), we proceeded to write our model in the VAR form:

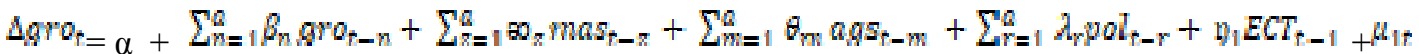

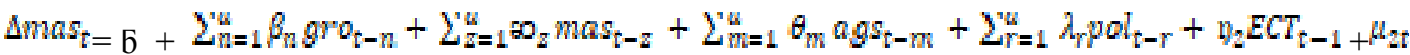

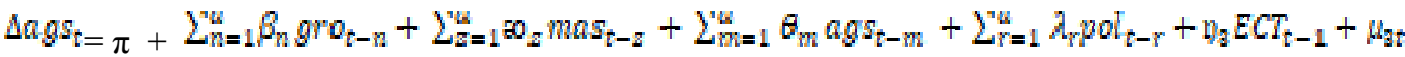

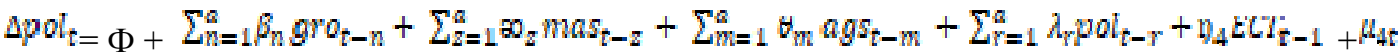

In the above specified VAR model, a is the optimal lag length, and the lag length is reduced by $1, \alpha, 5, \pi, \Phi$ which are the intercepts. $\beta_{\mathrm{n}}, \mathrm{\infty}_{\mathrm{z}}, \theta_{\mathrm{m}}, \lambda_{\mathrm{s}}$ are the short-run dynamic coefficients of our model's adjustment to the long-run equilibrium. $E C T_{t-1}$ is the error correction term, which indicates the lagged value of the residuals generated from the cointegrating regression of the regressand on the independent variable. It consists of long-run estimates deduced from the long-run cointegrating relationship. $\mu_{1 t}, \mu_{2 t}, \mu_{2 t}$, and $\mu_{h t}$ denote the residuals in the equations.

\subsection{The Stationary Test}

In this study, we utilised the Augmented Dickey-Fuller and Phillips-Perron unit root tests to determine the stationary condition of our four variables. The null hypothesis was that the variable used was not stationary and had a unit root; the alternative hypothesis was that the variable was stationary and had no unit root. If the test statistic is greater than the $5 \%$ critical value, the null hypothesis is rejected. Drawing support from our lag optimal selection criteria with the Akaike Information Criterion, indicating two lags, as presented in Table 2, we observed that our four variables of interest were not stationary at level zero, but stationary at the first difference, I(1), as shown in Table 3 and 4 for Augmented Dickey-Fuller and Phillips-Perron unit root tests, respectively.

Given the outcome of our unit root test above, which indicated that our variables were stationary at order one, we performed the required Johansen cointegration test.

\subsection{The Cointegration Test}

We presented the results of the cointegration tests, using the approach of Johansen and Juselius (1990), in Table 
5. The null hypothesis was that no cointegration exists when the value of the trace statistics was below the $5 \%$ critical value, while the alternative statistics was that the trace statistics value was greater than the $5 \%$ critical value. From Table 5, our trace statistics suggested the existence of one cointegrating vector, because 66.26557 was higher than 47.85613 with a statistically significant probability value of 0.0004 . The outcome suggested that there exists a long-run relationship among the four variables utilised in this study. This implied that these variables are not likely to move too far away from each other, thereby indicating proximity or co-movement among gro, mas, ags, and pol. Since our variables are cointegrated of order one, we performed the VEC model as follows:

\subsection{Vector Error Correction Model}

From the results in Table 6, we found that there exists a positive long-run relationship among mas, ags, and pol with gro at the $5 \%$ level of significance, given that the respective $t$ statistics are greater than 2 . Furthermore, we deduced the following short-run outcomes based on the VEC estimates presented in Table 7:

1. There was no evidence of a significant yearly adjustment of gro deviation from its cointegrating value from 1999 to 2019, since the adjustment speed was -0.152 and statistically insignificant at the 5\% level. By implication, a potential fluctuation in the long-run relationship did not cause gro to counteract an adjustment with the error. In the context of mas alone, evidence abounds for a statistically significant yearly adjustment, as indicated in Table 6 .

2. The mas had a positive but statistically insignificant impact (0.819) on the estimated gro. This indicated that a one-period lag of mas had no significant effect on gro between 1999 and 2019, even in the short run, ceteris paribus.

3. The ags recorded a negative but statistically insignificant value contrary to the expectation of the Nigerian government. Nigeria imports a substantial quantity of food items and its agricultural methods are traditional to a large extent. These were indicators to deduce that the net effect of the ags was unsatisfactory. The outcome indicated that one-period lag in ags had no significant implication on gro between the mentioned timeframe.

4. One percentage point change in pol led to a statistically insignificant decrease in gro in the short run, ceteris paribus. Nigeria runs one of the most expensive political systems in the Sub-Saharan Africa, with an astronomically high salary of the political officeholders. Besides, substantial evidence from the literature suggests that the Nigerian political space potentially hinders economic growth for reasons like weak political institutions and excessive monetisation of politics.

5. The Granger Causality Result

Table 8 shows the Granger Causality results for our VEC model. Given the output of the block exogeneity Wald test, we inferred the following:

a. Mas did not significantly Granger-cause gro. The chi-square statistic was higher than 0.05 for gro between 1999 and 2019.

b. Ags failed to significantly Granger-cause gro, which was deduced from the chi-square value. It was higher than 0.05 for gro from 1999 to 2019.

c. Pol did not significantly Granger-cause gro. The chi-square statistic was higher than 0.05 for gro between 1999 and 2019.

d. Gro did not significantly Granger-cause mas, ags, and pol given their respective chi-square statistics from 1999 to 2019.

\section{Impulse Response Function (IRF)}

Economic literature shows that individual coefficients within an estimated error correction model are challenging to interpret, especially with the VAR model. Therefore, the application of the IRF is important for analysing the dynamic properties of the VEC model. The IRF demonstrates the response of the regressand in the VAR system

to the shocks, like $\mu_{1}, \mu_{2}, \mu_{2}$, and $\mu_{4}$. It traces out the impacts of shocks over several periods in the future. In this study, it traced the shocks for 10 years in the future. Based on Figure 1, we forecasted the following:

i. We observed that the response of mas to a one standard deviation shock in gro was slightly negative in the first period, which changed to positive in the second period, became negative again in the third period, and remained consistent on the negative trends till the tenth period.

ii. The corresponding response of ags to one-unit positive innovation led to a higher positive impact in the first period, which declined but remained positive between the second and fourth periods, and continued to be positive till the tenth year. This outcome might be the underlining reason of the Nigerian government to primarily focus on agriculture led diversification.

iii. One standard deviation shock to pol led to an increasingly positive impact on gro from period one to period two, and it declined sharply in period three, remaining positive. It increased slightly in 
period four and remained consistent until the tenth year. This result underscored the fact that political institutions are vital for economic growth.

Figure 1: Impulse Response Function (IRF) Analysis in VEC Model

\subsection{Variance Decomposition}

This study traced the variance decomposition of each of the variables for 10 years. Variance decomposition illustrated the essence of each random innovation or one standard deviation of the endogenous variables in our VEC model. Table 9 presents the output of our variance decomposition forecast error. From the results, the following points were deduced:

1. We observed that an insignificant proportion of the variance in gro was traceable to the shocks in mas, ags, and pol, which was about $15.9 \%$ in aggregate during the 10 years.

2. For mas, a significant proportion of variance was traceable to its own shock. This indicated that another explanatory variable in the system of the variance decomposition had limited influence on ma, except for pol, which averaged over $20 \%$ from the third year and increased to $30.93 \%$ in the tenth year.

3. Approximately, about $50 \%$ of the variance in the ags was traceable to the shocks in mas. The rest of the variance was explained by the combined shocks in gro, ags, and pol. This indicated that the manufacturing sector has a potential influence on the agricultural value chain system in Nigeria.

4. A significant proportion of the variance in pol was attributed to the combined shocks in ags and pol, which was about $80 \%$ over the ten years. The pol shocks started strongly, with about $58.22 \%$ in year one, which continued to decline till year ten, at $46.74 \%$.

\subsection{Diagnostic Tests}

To determine the robustness of our VEC output, we carried out specific post-estimation tests and presented their output in Table 10 below:

From Table 10, the null hypothesis of the Jarque-Bera normality test is that all our variables have a normal distribution, while the alternative hypothesis is that none of them have a normal distribution at 5\% critical value. Given our chi-square probability value of 0.16830 , which was clearly above the threshold of $0.05 \%$ critical value, we accepted the null hypothesis, thereby concluding that all our variables have a normal distribution.

The Lagrange Multiplier test of autocorrelation in Table 10 indicated that we cannot reject the null hypothesis of no serial correlation in the residuals at all lags(lag 1 and 2) and significance level.

The chi-square probability value for the VEC residual heteroscedasticity was 0.7074 , which implied that the residuals of the variables in the model, were homoscedastic. From the above post-estimation results, we safely concluded that our VAR model was robust and valid.

\section{Conclusions}

This paper examined the relationship between diversification and the growth of the Nigerian economy during the first 20 years of uninterrupted democratic government in Nigeria. Among the various outcomes, we found cointegration among the variables used along with a long-run equilibrium relationship among them. This implied that the vital economic sectors in Nigeria, such as the manufacturing and the agriculture, move together in the long run, incorporating the effects of the political rights of the Nigerian people. Further, evidence from the estimated VEC model demonstrated that the one-period lag of the manufacturing sector had a positive but statistically insignificant effect on the economic growth in Nigeria from 1999 to 2019.

Our results indicated that despite the persistent attempt of the Nigerian government to focus diversification on agriculture, this sector had a negative and insignificant effect on the economic growth in Nigeria between 1999 and 2019. The level of productivity in the Nigerian agricultural sector is low. Moreover, agricultural employment generation has been declining since the discovery of oil. Disregard for this sector, along with rural to urban migration, justifies the negative relationship between the agricultural sector and the economic growth in Nigeria.

With the introduction of democratic government in Nigeria, it was largely expected that an improvement in the political participation of the Nigerian population through the election of qualified public officers would augment the prerequisite understanding of the workings of a diversified economy. However, this study showed that the political rights of the Nigerian population had a negative and insignificant effect on the economic growth of the country during the study period. Evidence from the literature shows that the democratic experience of Nigeria is fragile with somewhat weak political institutions that are incapable to support the economic growth, as expected.

The outcome of our Granger Causality tests provided no evidence of causality between the regressand (gro) and the regressors (mas, ags, and pol) during the mentioned timeframe. One of the policy implications from this outcome was that the contributions of the non-oil sectors to the Nigerian economic growth was insignificant and therefore, diversification of the economy to non-oil sectors was meaningless for economic growth. Further, our 
results also suggested that the largest proportion of shocks in the manufacturing sector was traceable to itself. This sector was also accountable for a substantial shock in the agricultural sector and on the political rights of the citizens.

In light of the above findings, the need of the hour is to adopt a policy that promotes large-scale mechanisation of the agricultural sector and curtails importation of food items. The development of the agricultural sector must come with infrastructural growth in the rural areas to curb the persistent rural to urban migration. The manufacturing sector can do better if the government protects the infant and domestic manufacturing companies from international competition. Efforts should be made by the Nigerian government to promote and sustain the slogan 'buy and use made in Nigeria'. The manufacturing sector of the Nigerian economy is partly dependent on local consumption and demand; therefore, the creation and protection of the markets for the domestic manufacturing companies are essential. Above all, there is a need to develop the political rights and consciousness of the population to elect good political office holders with sound economic management skills and knowledge.

\section{References}

Abogan, O.P.; Akinola, E.B. and Baruwa, O.I. (2014). Non-Oil Export and Economic Growth in Nigeria (19802011). Journal of Research in Economics and International Finance, 3, 1-11.

Adenugba, A. A and Dipo, S. O.(2013). Non-Oil Exports in the Economic Growth of Nigeria: A Study of Agricultural and Mineral Resources. Journal of Educational and Social Research, [S.1.], v. 3, n. 2, p. 403, ISSN 2240-0524. Available at: https://www.mcser.org/journal/index.php/jesr/article/view/187

Ayodele, O.S; Akongwale, S and Udefuna, P.N.(2013). Economic diversification in Nigeria: Any role for solid mineral development? Mediterranean Journal of Social Sciences, 14(60, 691-703. https://doi.org/10.5901/mjss.2013.v4n6p691.

Aghion \& Howitt,( 1992). "A Model of Growth Through Creative Destruction," Scholarly Articles 12490578, Harvard University Department of Economics.

Arip, Mohammad; Affendy; Yee, Lau Sim and Abdul Karim, Bakri (2010). Export Diversification and Economic Growth in Malaysia. [online] Available : http://mpra.ub.uni-muenchen.

Central Bank of Nigeria Statistical Bulletin(2020).

Collier, P. and Hoeffler, A. (2005). 'Resource rents, governance, and conflict', Journal of Conflict Resolution.

Dickey, D. and Fuller W. (1981). "Likelihood Ratio Statistics for Autoregressive Time Series with a Unit Root" Econometrica, 49: 1057-1072.

Esu, G.E and Udonwa, U(2015). Economic diversification and economic growth: Evidence from Nigeria. Journal of Economics and Sustainable Development, 6(16),56-68. Available at:https:/tinyurl.com.ruchumk.

Granger, C.W.J. (1986). Developments in the study of cointegrated economic variables, Oxford Bulletin of Economics and Statistics 48, 213-228.

Godwin and Ubong (2015). Economic Diversification and Economic Growth: Evidence from Nigeria. Journal of Economics and Sustainable Development. 6

Grossman, G. and Helpman, E. (1991). Innovation and Growth in the Global Economy, MIT Press Cambridge, MA.

Johansen, S. and K. Juselius (1990). "Maximum Likelihood Estimation and Inference on Cointegration with Applications to Demand for Money" Oxford Bulletin of Economics and Statistics 52, 169-210.

Johansen, S. and Juselius, K. (1992) Testing Structural Hypotheses in a Multivariate Cointegration Analysis at the PPP and the Uncovered Interest Parity for the U.K. Journal of Econometrics, 53, 211-244. https://doi.org/10.1016/0304-4076(92)90086-7

Johansen, S. and Juselius, K. (1994) Identification of the Long-Run and the Short-Run Structure. An Application of the ISLM Model. Journal of Econometrics, 63, 7-36. http://dx.doi.org/10.1016/0304-4076(93)01559-5

Mehlum, H., Moene, K. and Torvik, R. (2006). 'Institutions and the resource curse', Economic Journal, 116(508), pp. 1-20. DOI: $10.1111 /$ j.1468-0297.2006.01045.x.

National Bureau of Statistics, Nigeria; Annual Report :(2010,2015)

OECD/WTO (2019), Aid for Trade at a Glance 2019: Economic Diversification and Empowerment, OECD Publishing, Paris, https://doi.org/10.1787/18ea27d8-en.

Olaleye, S.O; Eduan, F and Taiwo, S.B (2013). Export diversification and economic growth in Nigeria: An empirical test of relationship using a Granger Causality Test. Journal of Emerging Trends in Economics and Management Sciences (JETEMS),5(1),70-79.

Onodugo, V.A(2013). Can Private Sectors Facilitate Economic Growth and Realisation of MDG in Developing Countries? Evidence from Nigeria. Journal of Social Sciences, Vol 3, No 1, Pp 83-96,22.

Olayiwola, K. and Okodua, H. (2013) Foreign Direct Investment, Non-Oil Exports and Economic Growth in Nigeria: A causality analysis. Asian Economic and Financial Review, 3, 1479-1496.

Onayemi, S.O. and Akintoye, I. ( 2009). Diversifying the Productive Base of Nigeria, an Econometric Approach 
to the Assessment of Non-Oil Export Promotion Strategies. International Research Journal of Finance and Economics. 1. 209-222.

Odularu, G.O (2010). "Crude oil and Nigerian Economic Performance”. Oil and Gas Business.

Phillips, P.C.B. and Perron, P (1988). Testing for a unit root in time series regression. Biometrika 75, 335-346.

Romer, P.(1990). Endogenous Technological Change, The Journal of Political Economy, Vol. 98, No. 5, Part 2: The Problem of Development: A Conference of the Institute for the Study of Free Enterprise Systems. Pp. S71-S102.

Sevil, A (2017). The Curse of Natural Resources, Palgrave Macmillian, Pg. 7-59,121-141.

Sachs, J. and Warner, A. (2001). 'Natural Resource Abundance and Economic Growth', NBER Working Paper Series, p. 5398. DOI: 10.3386/w5398.

Solow, R.M (2000). Growth Theory, 2nd Edition, Oxford University Press.

Solow, R. M. (1956). A contribution to the theory of economic growth. Quarterly Journal of Economics, 70, 6594.

Soludo, C.C. (2007). Macroeconomics, monetary and financial sector developments on financial and payment system reforms in the country. Economic and financial Review, 30(1):32-69.

Wooldridge, J (2016). Introductory Econometrics: A Modern Approach (Upper-Level Economics Titles) 6th edition (ISBN: 9781305270107)

World Bank, World Development Indicators (2020).

Young, A (1995). The tyranny of numbers: Confronting the statistical reality of the East Asian growth experience. Quarterly Journal of Economics,110:641-680.

\begin{tabular}{|l|l|l|l|}
\hline \multicolumn{3}{|l|}{ Table 1: GDP and Sectoral Contributions to GDP in Percentage :1999-2019 } \\
\hline year & GDP (Constant 2010 \$) & $\begin{array}{l}\text { *Agriculture Sector Contributions } \\
\text { as of GDP }\end{array}$ & $\begin{array}{l}\text { *Manufacturing } \\
\text { Contributions as \% of GDP }\end{array}$ \\
\hline 1999 & 1350.98 & 0.21 & 0.07 \\
\hline 2000 & 1383.67 & 0.20 & 0.06 \\
\hline 2001 & 1429.2 & 0.20 & 0.07 \\
\hline 2002 & 1607.24 & 0.27 & 0.06 \\
\hline 2003 & 1682.1 & 0.26 & 0.06 \\
\hline 2004 & 1791.26 & 0.25 & 0.06 \\
\hline 2005 & 1857.93 & 0.25 & 0.06 \\
\hline 2006 & 1919.72 & 0.26 & 0.06 \\
\hline 2007 & 1993.1 & 0.26 & 0.07 \\
\hline 2008 & 2072.27 & 0.25 & 0.07 \\
\hline 2009 & 2179.99 & 0.25 & 0.07 \\
\hline 2010 & 2292.45 & 0.24 & 0.07 \\
\hline 2011 & 2350.34 & 0.23 & 0.07 \\
\hline 2012 & 2384.95 & 0.24 & 0.08 \\
\hline 2013 & 2476.86 & 0.23 & 0.09 \\
\hline 2014 & 2563.9 & 0.23 & 0.09 \\
\hline 2015 & 2563.15 & 0.23 & 0.09 \\
\hline 2016 & 2456.31 & 0.25 & 0.09 \\
\hline 2017 & 2412.37 & 0.25 & 0.09 \\
\hline 2018 & 2395.97 & 0.25 & 0.09 \\
\hline 2019 & 2386.87 & 0.25 & 0.09 \\
\hline Source: & World Bank's World Development Indicators (2020) and *Central Bank of Nigeria Statistical \\
\hline Bulletin $(2019)$ & & \\
\hline & & & \\
\hline
\end{tabular}

Table 2: Lag Selection Criteria Result

\begin{tabular}{|l|l|l|l|l|}
\hline \multirow{2}{*}{} & \multicolumn{4}{|c|}{ Criterion } \\
\cline { 2 - 5 } & FPE & AIC & SC & HQC \\
\hline Lag & 1 & 2 & 2 & 1 \\
\hline Source: Author's Computation. \\
\hline
\end{tabular}

FPE=Final Prediction Error

$\mathrm{AIC}=$ Akaike Information Criterion

$\mathrm{SC}=$ Schwartz Criterion

HQC=Hannan-Quinn Criterion 
Table 3: Unit Root Tests for Stationarity with Augmented Dickey-Fuller in levels and first difference

\begin{tabular}{|l|l|l|l|l|l|l|}
\hline \multirow{2}{*}{ Series } & \multicolumn{4}{l|}{ Augmented Dickey-Fuller at Level } & \multicolumn{3}{l|}{ Augmented Dickey-Fuller at first difference } \\
\cline { 2 - 7 } & $\begin{array}{l}\text { Test } \\
\text { Statistics }\end{array}$ & $\begin{array}{l}\text { 5\% Critical } \\
\text { Value }\end{array}$ & Outcome & Test Statistics & 5\% Critical Value & Outcome \\
\hline Gro & -2.530958 & -3.020686 & $\mathrm{I}(0)$ & -6.618872 & -3.052169 & $\mathrm{I}(1)$ \\
\hline Mas & -1.728049 & -3.029970 & $\mathrm{I}(0)$ & -3.199796 & -3.029970 & $\mathrm{I}(1)$ \\
\hline Ags & -2.629544 & -3.020686 & $\mathrm{I}(0)$ & -4.765768 & -3.029970 & $\mathrm{I}(1)$ \\
\hline Pol & -1.212436 & -3.020686 & $\mathrm{I}(0)$ & -4.197402 & -3.029970 & $\mathrm{I}(1)$ \\
\hline \multicolumn{6}{|l|}{ Source: Author's Computations using Eviews 10.}
\end{tabular}

Table 4: Unit Root Tests for Stationarity with Phillips-Perron in levels and first difference

\begin{tabular}{|l|l|l|l|l|l|l|}
\hline \multirow{2}{*}{ Series } & \multicolumn{3}{|l|}{ Phillips-Perron Unit Root test at level } & \multicolumn{3}{l|}{ Phillips-Perron Unit Root test at $1^{\text {st difference }}$} \\
\cline { 2 - 7 } & $\begin{array}{l}\text { Test } \\
\text { Statistics }\end{array}$ & $\begin{array}{l}5 \% \text { Critical } \\
\text { Value }\end{array}$ & Outcome & $\begin{array}{l}\text { Test } \\
\text { Statistics }\end{array}$ & 5\% Critical Value & Outcome \\
\hline Gro & -2.623365 & -3.020686 & $\mathrm{I}(0)$ & -6.787924 & -3.029970 & $\mathrm{I}(1)$ \\
\hline Mas & -2.935499 & -3.020686 & $\mathrm{I}(0)$ & -3.260383 & -3.029970 & $\mathrm{I}(1)$ \\
\hline Ags & -2.512048 & -3.020686 & $\mathrm{I}(0)$ & -4.871913 & -3.029970 & $\mathrm{I}(1)$ \\
\hline Pol & -1.207224 & -3.020686 & $\mathrm{I}(0)$ & -4.423842 & -3.029970 & $\mathrm{I}(1)$ \\
\hline \multicolumn{7}{|l|}{ Source: Author's Computations using Eviews 10.} \\
\hline
\end{tabular}

Table 5: Johansen Co-integration Test Result Showing Number of Cointegrating Vectors

\begin{tabular}{|l|l|l|l|l|l|}
\hline $\begin{array}{l}\text { Hypothesised Number of } \\
\text { Cointegration }\end{array}$ & $\begin{array}{l}\text { Trace } \\
\text { Statistics }\end{array}$ & $\begin{array}{l}5 \% \\
\text { Value }\end{array}$ & $\begin{array}{l}\text { Critical } \\
\text { Value }\end{array}$ & Decision \\
\hline None* & 66.26557 & 47.85613 & 0.0004 & Cointegrating \\
\hline At most 1 & 28.72688 & 29.79707 & 0.0660 & $\begin{array}{l}\text { Not } \\
\text { Cointegrating }\end{array}$ \\
\hline At most 2 & 11.69105 & 15.49471 & 0.1723 & $\begin{array}{l}\text { Not } \\
\text { Cointegrating }\end{array}$ \\
\hline At most 3 & 2.292557 & 3.841466 & 0.1300 & $\begin{array}{l}\text { Not } \\
\text { Cointegrating }\end{array}$ \\
\hline
\end{tabular}

Source: Author's Computation using Eviews 10.

\begin{tabular}{|c|c|}
\hline Co-integration Equation & Long Run Solution \\
\hline Gro & 1.000000 \\
\hline Mas & $\begin{array}{l}-1.851947 \\
(-8.53288)\end{array}$ \\
\hline Ags & $\begin{array}{l}-209.2500 \\
(-8.57492)\end{array}$ \\
\hline Polright & $\begin{array}{l}-11.24948 \\
(-13.8758)\end{array}$ \\
\hline Constant & 109.7313 \\
\hline \multicolumn{2}{|c|}{$\begin{array}{l}\text { Note: } t \text { statistics in parenthesis. The signs of the coefficients would become opposite in the long -ru } \\
\text { interpretation. }\end{array}$} \\
\hline \multicolumn{2}{|c|}{ 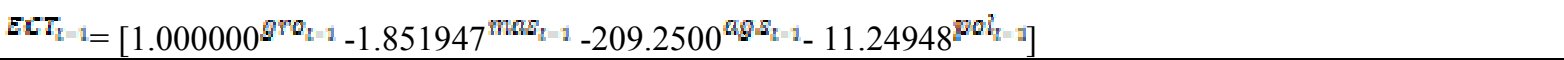 } \\
\hline
\end{tabular}




\begin{tabular}{|c|c|c|c|c|}
\hline Equation & $\mathrm{D}$ (Gro) & $\mathrm{D}$ (Mas) & $\mathrm{D}(\mathrm{Ags})$ & $\mathrm{D}(\mathrm{Pol})$ \\
\hline CointEq1 & $\begin{array}{l}-0.151786 \\
(-0.50191)\end{array}$ & $\begin{array}{l}0.154426^{*} \\
(2.27615)\end{array}$ & $\begin{array}{l}0.001186 \\
(0.67803)\end{array}$ & $\begin{array}{l}0.040502 \\
(1.05960)\end{array}$ \\
\hline $\mathrm{D}$ (Gro)[-1] & $\begin{array}{l}-0.022721 \\
(-0.06013)\end{array}$ & $\begin{array}{l}0.025359 \\
(0.29917)\end{array}$ & $\begin{array}{l}-0.000960 \\
(-0.43928)\end{array}$ & $\begin{array}{l}-0.013547 \\
(-0.28367)\end{array}$ \\
\hline $\mathrm{D}$ (Mas)[-1] & $\begin{array}{l}0.819133 \\
(0.63216)\end{array}$ & $\begin{array}{l}0.126143 \\
(0.43394)\end{array}$ & $\begin{array}{l}-0.001546 \\
(-0.20621)\end{array}$ & $\begin{array}{l}-0.102759 \\
(-0.62743)\end{array}$ \\
\hline $\mathrm{D}(\mathrm{ags})[-1]$ & $\begin{array}{l}-56.30579 \\
(-1.00028)\end{array}$ & $\begin{array}{l}8.262712 \\
(0.65430)\end{array}$ & $\begin{array}{l}-0.031083 \\
(-0.09547)\end{array}$ & $\begin{array}{l}0.525640 \\
(0.07388)\end{array}$ \\
\hline $\mathrm{D}(\mathrm{Pol})[-1]$ & $\begin{array}{l}-1.339077 \\
(-0.35781) \\
\end{array}$ & $\begin{array}{l}0.661634 \\
(0.78805)\end{array}$ & $\begin{array}{l}0.014720 \\
(0.68002)\end{array}$ & $\begin{array}{l}0.344087 \\
(0.72743) \\
\end{array}$ \\
\hline $\mathrm{C}$ & $\begin{array}{l}0.187095 \\
(0.20913)\end{array}$ & $\begin{array}{l}-0.067237 \\
(-0.33501)\end{array}$ & $\begin{array}{l}0.002996 \\
(0.57892)\end{array}$ & $\begin{array}{l}-0.070502 \\
(-0.62350)\end{array}$ \\
\hline R-Squared & 0.199662 & 0.515812 & 0.063927 & 0.094869 \\
\hline F Statistics & 0.648629 & 2.769818 & 0.177561 & 0.272514 \\
\hline Likelihood & -47.60828 & -19.21119 & 50.29202 & -8.309410 \\
\hline $\mathrm{AIC}$ & 5.642977 & 2.653810 & -4.662318 & 1.506254 \\
\hline \multicolumn{5}{|c|}{$\Delta^{g r o_{l}}=0.187-0.023 \Delta^{g r o_{l-1}}+0.819 \Delta^{m s_{l-1}}-56.306 \Delta^{a g s_{l-1}}-1.339 \Delta^{p a l_{l-1}}-0.152^{E C \tau_{l-1}}$} \\
\hline \multicolumn{5}{|c|}{ Note: t- statistics in parentheses. } \\
\hline \multicolumn{5}{|c|}{ Source: Author's Computation using Eviews 10.} \\
\hline
\end{tabular}

\begin{tabular}{|l|l|l|l|l|l|}
\hline \multicolumn{6}{|l|}{ Table 8: Block Exogeneity Wald Test or Granger Causality Test Results } \\
\hline Dependent Variables & \multicolumn{2}{l|}{ Chi-Square Statistics P-Values } & Pol & Joint Causality \\
\hline & Gro & mas & ags & 0.128026 & 1.580388 \\
\hline Gro & - & 0.399626 & 1.000558 & $(0.7205)$ & $(0.6638)$ \\
& & $(0.5273)$ & $(0.3172)$ & 0.621017 & 2.540279 \\
mas & 0.089500 & - & 0.428115 & $(0.4307)$ & $(0.4681)$ \\
\hline ags & $(0.7648)$ & & $(0.5129)$ & 0.462421 & 0.547662 \\
& 0.192966 & 0.042523 & - & $(0.4965)$ & $(0.9083)$ \\
\hline Pol & $(0.6605)$ & $(0.8366)$ & & - & 0.429254 \\
& 0.080470 & 0.393674 & 0.005458 & $(0.9341)$ \\
\hline P-Values in parentheses ( * Denotes 5\% level of significance) & $(0.9411)$ & & \\
\hline
\end{tabular}

\begin{tabular}{|l|l|l|l|l|l|l|l|l|l|l|l|l|l|l|l|l|l|}
\hline \multicolumn{10}{|c|}{ Table 9: Variance Decompositions } \\
\hline
\end{tabular}




\begin{tabular}{|l|l|}
\hline Table 10: Diagnostic Tests \\
\hline Diagnostic Tests & $\begin{array}{l}\text { Chi-Square Probability } \\
\text { Value }\end{array}$ \\
\hline Jarque-Bera Normality test (ALL) & 0.16830 \\
\hline LM Test of Autocorrelation \\
\hline Lag 1 & 0.45914 \\
\hline Lag 2 & 0.88663 \\
\hline $\begin{array}{l}\text { VEC Residual Heterosckedasticity } \\
\text { Joint Test }\end{array}$ & 0.7074 \\
\hline Source: Author's Computation. \\
\hline
\end{tabular}

\begin{tabular}{|l|l|l|l|l|l|}
\hline Table 11: Descriptive Statistics & Mean & SD & Min & Max & N \\
\hline Variable [Notation] & 2.711 & 3.54 & -4.17 & 12.46 & 21 \\
\hline Per capita Real GDP Growth Rate [gro] & 10 & 2.48 & 6.55 & 16.26 & 21 \\
\hline Manufacturing Value Added as Percentage of GDP [Mas] & 0.24 & 0.02 & 0.2 & 0.27 & 21 \\
\hline Agriculture share as Percentage of GDP [Ags] & 3.91 & 0.05 & 3 & 5 & 21 \\
\hline Political Right of the Population [Pol] &
\end{tabular}

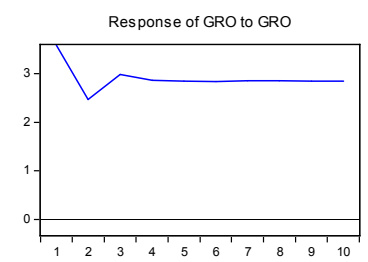

Response to Cholesky One S.D. (d.f. adjusted) Innov ations
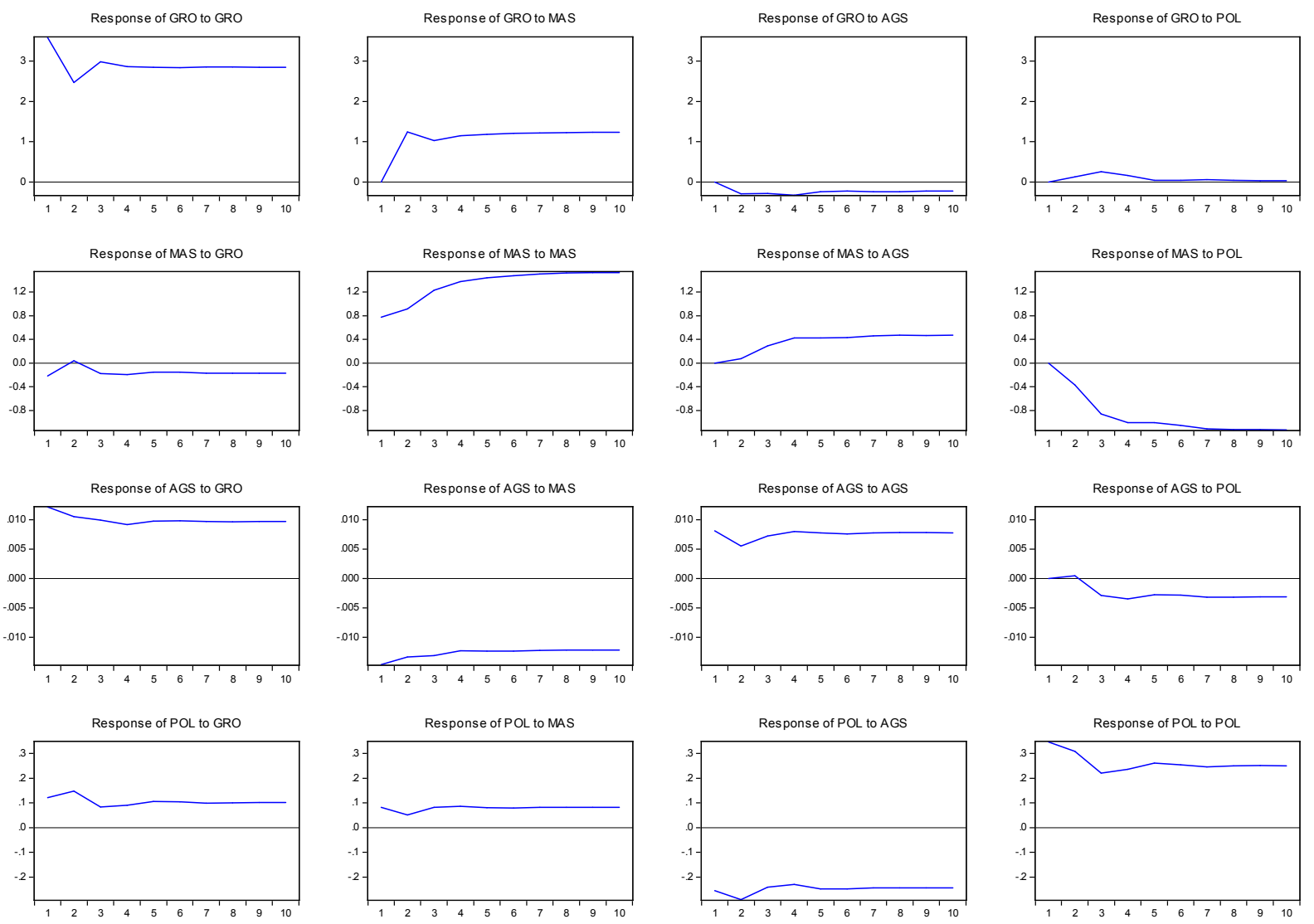